\title{
Review
}

Physiology

Published online: November 6, 2014

DOI: $10.1159 / 000368266$

\section{Effect of Mineralocorticoids on Acid-Base Balance}

\author{
Carsten A. Wagner \\ Institute of Physiology, University of Zurich, Zurich, Switzerland
}

\section{Key Words}

Mineralocorticoids · Acid-base balance · Aldosterone .

Acidosis

\begin{abstract}
Aldosterone is classically associated with the regulation of salt and potassium homeostasis but has also profound effects on acid-base balance. During acidosis, circulating aldosterone levels are increased and the hormone acts in concert with angiotensin II and other factors to stimulate renal acid excretion. Pharmacological blockade of aldosterone action as well as inherited or acquired syndromes of impaired aldosterone release or action impair the renal response to acid loading and cause hyperkalemic renal tubular acidosis. The mineralocorticoid receptor (MR) mediating the genomic effects of aldosterone is expressed in all cells of the distal nephron including all subtypes of intercalated cells. In acidsecretory type A intercalated cells, aldosterone stimulates proton secretion into urine, whereas in non-type A intercalated cells, aldosterone increases the activity of the luminal anion exchanger pendrin stimulating bicarbonate secretion and chloride reabsorption. Aldosterone has also stimulatory effects on proton secretion that may be mediated by a nongenomic pathway. In addition, aldosterone indirectly stimulates renal acid excretion by enhancing sodium reabsorption through the epithelial sodium channel ENaC. Increased sodium reabsorption enhances the lumen-negative transepi-
\end{abstract}

thelial voltage that facilitates proton secretion by neighboring intercalated cells. This indirect coupling of sodium reabsorption and proton secretion is thought to underlie the fludrocortisone-furosemide test for maximal urinary acidification in patients with suspected distal renal tubular acidosis. In patients with CKD, acidosis-induced aldosterone may contribute to progression of kidney disease. In summary, aldosterone is a powerful regulator of renal acid excretion required for normal acid-base balance.

(c) 2014 S. Karger AG, Basel

\section{Introduction}

Systemic acid-base homeostasis is maintained and controlled by the concerted action of various organs including lungs, kidneys, liver, bone, skeletal muscle, and intestine. Among them, lungs and kidneys play arguably the most important role as evident from respiratory disorders and inherited or acquired renal diseases.

Daily metabolism in an adult healthy person with standard diet and average physical activity produces approximately $1 \mathrm{mmol}$ of protons per kilogram body weight which must be buffered or eliminated. Elimination and buffering of protons critically depend on the kidney. Approximately $20 \mathrm{mmol}$ of acid are absorbed from diet and an additional $10 \mathrm{mmol}$ base equivalents are lost due to intestinal secretions. The major acid load comes from

\section{KARGER}

E-Mail karger@karger.com

www.karger.com/nep
(C) 2014 S. Karger AG, Basel

$1660-2137 / 14 / 1282-0026 \$ 39.50 / 0$
Prof. Dr. Carsten A. Wagner

Institute of Physiology, University of Zurich

Winterthurerstrasse 190

CH-8057 Zurich (Switzerland)

E-Mail wagnerca@access.uzh.ch 
daily metabolism liberating around $15,000 \mathrm{mmol}$ of volatile acid in the form of $\mathrm{CO}_{2}$ that are eliminated by ventilation and $40 \mathrm{mmol}$ of non-volatile acids that require immediate buffering (mostly by bicarbonate) or direct renal excretion. The kidney contributes to buffering of acids by reabsorbing virtually all filtered bicarbonate and the de novo synthesis of bicarbonate from ammoniagenesis leading to the excretion of approximately $40 \mathrm{mmol}$ of ammonium into urine. Additionally, the kidneys excrete free protons that have to be buffered by urinary buffers, socalled titratable acids (mostly phosphate), thereby buffering and eliminating a total of $70 \mathrm{mmol}$ acid/day $[1,2]$.

The different nephron segments specifically contribute to the control of acid-base homeostasis by the kidney $[1,3,4]$. Proximal tubule segments are involved in bicarbonate reabsorption, ammoniagenesis, and determination of urinary excretion of titratable acids, the thick ascending limb of the loop of Henle (TAL) mostly reabsorbs bicarbonate, and the collecting ducts excrete protons and ammonium and are the major site of adapting and finetuning renal acid-base excretion [4].

Whether the proximal tubule and the thick ascending limb are directly regulated by aldosterone is controversial, whereas the functions of the distal convoluted tubule (DCT), connecting tubule and collecting duct system, collectively referred to as aldosterone sensitive distal nephron (ASDN), are directly and indirectly modulated by aldosterone [5-7].

Reabsorption of bicarbonate in the proximal tubule is mediated by the secretion of protons into primary urine by $\mathrm{Na}^{+} / \mathrm{H}^{+}$exchangers (NHEs) and proton pumps situated in the apical brush border membrane [8]. NHE3 (SLC9A3) is the major NHE isoform in adults [9]. NHE3 contributes also as a major mechanism to sodium reabsorption in the proximal tubule. Protons for NHEs and proton pumps are generated by intracellular carbonic anhydrases (mostly carbonic anhydrase II, CAII) [8]. The secreted protons combine in the luminal fluid with filtered bicarbonate to form carbon dioxide $\left(\mathrm{CO}_{2}\right)$ and water $\left(\mathrm{H}_{2} \mathrm{O}\right)$. This reaction is catalyzed by membrane-anchored extracellular carbonic anhydrases (mostly carbonic anhydrase IV, CAIV) [8]. $\mathrm{CO}_{2}$ diffuses into proximal tubule cells. Bicarbonate formed by rehydration of $\mathrm{CO}_{2}$ by intracellular carbonic anhydrases leaves proximal tubular cells across the basolateral cell membrane into blood via the electrogenic $\mathrm{Na}^{+}-\mathrm{HCO}_{3}$ cotransporter NBCe1 (SLC4A4) [10]. Another part of bicarbonate reabsorption occurs through the paracellular pathway due to solvent drag driven by the lumen-negative potential and the osmotic gradient built by active solute transport [8].
Bicarbonate not reabsorbed by the proximal tubule is reabsorbed in the TAL and the DCT. Thus, urine entering the collecting duct system contains only minute amounts of bicarbonate under conditions of acid-base balance. The mechanisms mediating bicarbonate reabsorption in the TAL are similar to the proximal tubule involving also NHE3 and proton pumps on the luminal membrane [11]. The exit pathways for bicarbonate across the basolateral membrane are not well defined. The electroneutral $\mathrm{Na}^{+}-$ $\mathrm{HCO}_{3}$ cotransporter NBCn1 is localized at the basolateral membrane but is thought to mediate rather bicarbonate uptake from blood required for ammonium reabsorption by the TAL [12].

The late section of the DCT is characterized by the presence of the first intercalated cells, which express luminal proton pumps (V-type $\mathrm{H}^{+}$-ATPases) and the basolateral chloride-bicarbonate exchanger (AE1).

Ammoniagenesis takes place only in the proximal tubule and serves the elimination of protons and the de novo generation of bicarbonate from the metabolism of glutamine. Glutamine is extracted from peritubular capillaries, in part mediated by the glutamine transporter SNAT3 (SLC38A3) at the basolateral membrane of proximal tubule cells $[13,14]$. Glutamine is further imported into mitochondria and metabolized by mitochondrial phosphate-dependent glutaminases and glutamate dehydrogenases to yield $\alpha$-ketoglutarate. These steps liberate two $\mathrm{NH}_{3}$ and one bicarbonate ion per glutamine. a-Ketoglutarate can then be further metabolized during gluconeogenesis or be converted to yield additional two $\mathrm{HCO}_{3}{ }^{-}$ions [2]. The bicarbonate synthesized during ammoniagenesis is exported via the basolateral NBCe1 bicarbonate transporter whereas $\mathrm{NH}_{3}$ either diffuses into urine and is trapped as $\mathrm{NH}_{4}{ }^{+}$after protonation or binds intracellularly protons and may be excreted into urine by the NHE3 exchanger instead of a proton.

Most of the ammonium excreted into urine is reabsorbed in the TAL by the NKCC2 cotransporter. $\mathrm{NH}_{4}{ }^{+}$is accumulated in the interstitium, a process that may require sulfatides binding ammonium $[15,16]$.

In the DCT and collecting duct system, at least two types of intercalated cells mediate acid or alkali excretion, respectively. Type A intercalated cells secrete protons and ammonium whereas type B intercalated cells excrete bicarbonate [3]. Type A intercalated cells produce bicarbonate from the hydration of $\mathrm{CO}_{2}$ and the excretion of protons by $\mathrm{V}$-type proton pumps (V-ATPases or $\mathrm{H}^{+}$ATPases) into urine $[4,17]$. Bicarbonate generation is catalyzed by the intracellular carboanhydrase II (CAII). The newly formed bicarbonate is secreted into the inter- 
stitium/blood across the basolateral membrane by the anion exchanger 1 (SLC4A1, AE1) [4]. Proton secretion drives ammonium excretion along the collecting duct. Ammonium excretion is mediated by specific transport proteins of the rhesus protein family, RhBG and RhCG $[4,15,18]$. RhCG is critical for renal ammonium excretion [19-21] and upregulated during acidosis [18].

Titratable acids are alkali buffers neutralizing protons in urine. The major urinary titratable acids are inorganic phosphate $\left(\mathrm{HPO}_{3}{ }^{2-}\right.$ and $\left.\mathrm{H}_{2} \mathrm{PO}^{3-}\right)$ and citrate [22]. The amount of available titratable acids depends mostly on their reabsorption in the proximal tubule since both phosphate and citrate are freely filtered and actively reabsorbed to some extent by the proximal tubule. The rate of reabsorption of phosphate by its major transporter $\mathrm{NaPiIIa}$ and citrate by $\mathrm{NaDC} 1$ is highly $\mathrm{pH}$-sensitive and in the case of phosphate reabsorption regulated by various hormones and factors [23-25]. Titratable acids are required to buffer protons as proton secretion by proton pumps is limited by the inability to pump protons against a proton gradient $>3.5 \mathrm{pH}$ units (intracellular $\mathrm{pH}$ approx. 7.2 vs. maximal urinary $\mathrm{pH} 4.5$ ).

Bicarbonate excretion is mediated by type $\mathrm{B}$ and non$\mathrm{A} /$ non- $\mathrm{B}$ intercalated cells that are present in the late DCT, CNT, and CCD. These cells express the chloridebicarbonate exchanger pendrin (SLC26A4) on the luminal membrane secreting bicarbonate into urine in exchange for urinary chloride $[26,27]$. Pendrin serves also chloride reabsorption and blood pressure regulation $[28$, 29].

A variety of factors, such as electrolyte status and hormones, influence renal acid-base metabolism and handling. Among them, angiotensin II and aldosterone play a very prominent role as discussed below. In addition, endothelin is a potent stimulus for renal acid excretion and may also enhance aldosterone secretion during acidosis [30-35]. Also insulin, prostaglandins, norepinephrine, glucocorticoids, and many more hormones modulate renal acid-base excretion [1]. This review will focus on the role of aldosterone in renal acid-base handling.

\section{Regulation of Aldosterone by Acid-Base Status}

Aldosterone secretion and levels are elevated during acidosis in humans and small and large animal models [36-44]. This increase in aldosterone levels is at least in part independent from changes in plasma levels of potassium and occurs even in the presence of a blockade of angiotensin II synthesis or action and with suppressed
ACTH levels, factors known to stimulate aldosterone secretion $[38,42,45]$.

TASK1 and TASK3 potassium channels that are very sensitive to external $\mathrm{pH}$ changes and whose activity is suppressed by physiological proton concentrations are highly expressed in zona glomerulosa cells and involved in the regulation of aldosterone secretion. However, their presence in the adrenal gland is not required for the aldosterone secretion stimulated by acidosis [45]. Thus, the acid-sensing mechanism responsible for aldosterone secretion by zona glomerulosa cells remains unknown but may reside in these cells as zona glomerulosa cells cultured in vitro are responsive to changes in $\mathrm{pCO}_{2}$ and $\mathrm{pH}$ of culture media [46].

\section{Aldosterone-Sensitive Regulation of Acid-Base Homeostasis}

Acidosis increases the circulating levels not only of aldosterone but also of angiotensin II [41, 42]. Angiotensin II acts on renal acid excretion by stimulating NHE3, $\mathrm{NBCe} 1$ and $\mathrm{H}^{+}$-ATPase-dependent bicarbonate reabsorption as well as ammonium excretion in the proximal tubule, and by stimulating $\mathrm{H}^{+}$-ATPase-mediated urinary acidification in the collecting duct [47-51]. Angiotensin II may also induce phosphate reabsorption thereby decreasing its delivery to the collecting duct and availability as buffer. Consequently, blockade of the angiotensin converting enzyme (ACE) or angiotensin II type 1 receptors delays the renal adaption to acidosis in healthy humans as well as in various animal models [42, 52-57].

Similarly, impaired aldosterone release or signaling affects the ability of the kidney to excrete acid and to respond to an acid load causing hyperkalemic distal renal tubular acidosis, also called type IV RTA [58]. Inhibition of aldosterone actions by mineralocorticoid receptor (MR) antagonists (e.g. spironolactone, eplerenone) reduces renal acid excretion in healthy humans $[42,59]$. Also patients with aldosterone deficiency due to adrenalectomy show type IV dRTA which is reversed with aldosterone substitution [60]. Mutations in the gene CYP11B2 encoding for the enzyme aldosterone synthase (corticosterone methyloxidase) catalyzing the last steps in the synthesis of aldosterone cause hyperreninemic hypoaldosteronism with hyperkalemia, low blood pressure, and metabolic acidosis [61]. Also inactivating mutations in the MR impairing aldosterone signaling cause similar symptoms [62].
28 
In contrast, syndromes of aldosterone excess cause metabolic alkalosis due to inappropriately high acid excretion [63] such as in Conn syndrome or syndromes of pseudohyperaldosteronism (with the exception of pseudohypoaldosteronism type II (Gordon syndrome) which features metabolic acidosis $[64,65])$. Mutations in CYP11B2 leading to aberrant stimulation by ACTH or CYP11B2 gene duplication can cause uncoupled and excessive aldosterone synthesis in [66,67]. More recently, mutations in the KCNJ5 potassium channel or the ATP1A1 $\left(\mathrm{Na}^{+} / \mathrm{K}^{+}\right.$-ATPase $\alpha$-subunit) and ATP2B3 (a $\mathrm{Ca}^{2+}$-ATPase) have been found that cause adrenal gland adenomas overproducing aldosterone $[68,69]$. In states of volume depletion and contraction of the extracellular fluid volume, the physiologic increase in aldosterone secretion contributes to the development of metabolic alkalosis as salt retention by the kidneys is linked to increased bicarbonate reabsorption and acid excretion (see also below). The mechanism has been attributed mostly to the depletion of chloride [70].

\section{Expression of Key Molecules of the Mineralocorticoid Response in Kidney Segments Involved in Acid-Base Handling}

The response of the kidney to mineralocorticoids depends on the expression of several key molecules required for aldosterone sensitivity and selectivity towards mineralocorticoids over glucocorticoids. Mineralocorticoids bind to the MR and induce its nuclear translocation where the ligand-receptor complex acts as transcription factor. Mineralocorticoid over glucocorticoid selectivity is ensured by the $11 \beta$-hydroxysteroid dehydrogenase type 2 (11 $\beta$-HSD2) inactivating $11 \beta$-hydroxyglucocorticoids and thereby protecting the MR from activation by glucocorticoids. At least in rat and mouse kidney, the MR is found in the cells lining the TAL, DCT, connecting tubule (CNT), and collecting duct system $[5,71]$. In the DCT, $\mathrm{CNT}$ and CD all cell types, e.g. principal (segment-specific) cells as well as all subtypes of intercalated cells, express the MR. No MR was detected by PCR and immunohistochemistry in proximal tubules and thin limbs of the loop of Henle. Similarly, 11 $\beta$-HSD2 is abundant in the cells of the TAL, DCT, CNT and CD but appears not to be expressed in intercalated cells. Its expression in the rat collecting duct, however, is downregulated during metabolic acidosis [72]. The glucocorticoid receptor (GR) is found in most cells along the entire nephron including also all subtypes of intercalated cells. Infusion of aldoste-

Mineralocorticoids in Acid-Base Balance rone into adrenalectomized rats induces translocation of both GR and MR into the nucleus, suggesting that the GR may mediate some effects of aldosterone in MR-negative cells. In contrast, corticosterone induces GR and MR translocation into the nucleus in all cells, positive or negative for $11 \beta$-HSD2, only at high concentrations whereas low doses have no effect on MR translocation in $11 \beta$-HSD2-positive cells [5]. Thus, glucocorticoids may stimulate MR in $11 \beta$-HSD2-negative intercalated cells and be responsible for some of the effects attributed to mineralocorticoids [71].

The MR is phosphorylated at various sites including at serine 483 , a site that modifies binding of aldosterone and glucocorticoids to the receptor. Phosphorylation of S483 reduces affinity and activation of the receptor. In kidney in vivo, most $M R$ is in the non-phosphorylated form except in intercalated cells that show a high degree of S483 phosphorylation [71]. MR phosphorylation is decreased in states of elevated aldosterone such as in volume depletion [71]. In contrast, in hyperkalemia, MR phosphorylation is increased and the receptor found mostly in the cytoplasm of intercalated cells whereas it is nuclear in principal cells. Angiotensin II may play a key role in regulation of the phosphorylation status of MR in intercalated cells and high angiotensin II reduces MR phosphorylation thereby providing a switch in the responsiveness of intercalated cells to aldosterone. The effects of angiotensin II may in part be mediated by the WNK4 kinase and the PP1 phosphatase [71].

The molecules mediating non-genomic rapid effects of aldosterone have not been identified to date. Possible candidates have been proposed and include GPR30 (GPER), a membrane-associated estrogen receptor. However, its role in physiological processes regulated by aldosterone in the kidney remained elusive [73].

\section{Regulation of Renal Acid-Base Transporters by Aldosterone}

Regulation of renal acid-base handling by aldosterone may occur by direct effects of aldosterone on target cells and molecules as well as by indirect effects requiring the crosstalk between different cells within a given nephron segment or between different nephron segments.

\section{Direct Regulation}

Genomic Effects of Aldosterone

Aldosterone stimulates urinary acidification and type A intercalated cell function. It may act directly on $\mathrm{H}^{+}$- 
ATPases and AE1 activity [74-79]. In aldosterone-deficient animals (e.g. due to adrenalectomy and repletion of glucocorticoids) urinary ammonium excretion is reduced but this may be mostly the result of reduced proton secretion and hyperkalemia impairing proximal ammoniagenesis [78].

Treatment of mice with the aldosterone analogue deoxycorticosterone acetate (DOCA) or $\mathrm{NaHCO}_{3}$ alone had no effect on the expression of the AE1 anion exchanger mRNA and protein abundance [80]. However, the combination of DOCA with $\mathrm{NaHCO}_{3}$ increased AE1 mRNA and protein, suggesting a combined action. Similarly, DOCA has no or only very little effects on mRNA and protein abundance of $\mathrm{H}^{+}$-ATPases in the collecting duct, suggesting that the stimulatory effects of aldosterone on proton secretion must be mediated by other mechanisms [Daryadel, Mohebbi, Wagner, unpubl. data]. Whether a combined treatment of angiotensin II and aldosterone would be able to increase AE 1 and $\mathrm{H}^{+}$-ATPase abundance has not been directly tested to our knowledge. However, infusion of angiotensin II over several days increases protein abundance of the intercalated cell-specific $\mathrm{B} 1 \mathrm{H}^{+}$-ATPase subunit [71]. Moreover, in mice lacking the $\mathrm{NaCl}$ cotransporter NCC, B1 expression is increased and this effect is abolished by either angiotensin receptor antagonists or MR blockers, suggesting that the combined action of angiotensin II and aldosterone may be required [71].

Similarly, regulation of pendrin in non-type A intercalated cells by aldosterone has been described [81, 82]. Whether this effect involves only redistribution of pendrin or increased abundance remained open. However, a subsequent detailed analysis suggested that DOCA alone does not alter pendrin abundance but that a combined effect of $\mathrm{NaHCO}_{3}$ and aldosterone could be observed [80]. Interestingly, expression of pendrin in other tissues such as kidney, heart, lung and thyroid gland is stimulated by aldosterone alone [83]. These in vivo data are in contrast to results obtained from in vitro promoter studies demonstrating reduced pendrin promoter activity with aldosterone [84]. As for the expression of the $\mathrm{B} \mathrm{H}^{+}$ATPase, pendrin expression is regulated by angiotensin II [85] and its expression is sensitive to angiotensin II and MR blockers [71].

Thus, there is mounting evidence for the genomic regulation of intercalated cell function by aldosterone and that complex interactions of aldosterone with angiotensin II and possibly further factors are involved. However, the exact pathways and the role of the MR in overall intercalated cell function remains to be further explored.
Non-Genomic Effects of Aldosterone on $\mathrm{H}^{+}$-ATPases

Aldosterone rapidly stimulates within $5 \mathrm{~min} \mathrm{H}^{+}$ATPase activity in acid-secretory type A intercalated cells of the mouse and human outer medullary collecting duct $[75,76]$. Stimulation occurred also in the presence of the MR antagonist spironolactone and was thus considered to be non-genomic. Moreover, corticosterones had no effect on $\mathrm{H}^{+}$-ATPase activity, suggesting specificity for aldosterone $[75,76]$.

The receptor mediating the rapid effects of aldosterone in intercalated cells is unknown. Interestingly, inhibition of $\mathrm{G}_{\alpha \mathrm{q}}$ proteins or phospholipase $\mathrm{C}$ activity blocked the effects of aldosterone, suggesting that either $\mathrm{G}$ protein-coupled receptors (GPCRs) mediate the effects or that additional signals through a GPCR play a permissive role in aldosterone signaling.

The MR may interact with epidermal growth factor receptor (EGFR) signaling by transactivation of EGFRdependent signaling cascades [86]. Whether such a crosstalk between MR and EGFR signaling is responsible for the rapid effects of aldosterone on $\mathrm{H}^{+}$-ATPase activity remains to be examined.

Injection of aldosterone in mice and rats caused a translocation of $\mathrm{H}^{+}$-ATPases to the luminal membrane with massive protrusion of the apical membrane indicating cellular remodeling and increased $\mathrm{H}^{+}$-ATPase density at the luminal membrane $[75,76]$. A similar stimulation of $\mathrm{H}^{+}$-ATPase activity, translocation of $\mathrm{H}^{+}$-ATPases, and remodeling of intercalated cells is observed after direct stimulation with PKA agonists [87]. Indeed, blockade of PKA prevented the stimulatory effect of aldosterone. Moreover, the signaling cascade involves rises in intracellular calcium, PKC and ERK1/2 [75, 76].

\section{Indirect Regulation}

Aldosterone stimulates sodium reabsorption in the late DCT and collecting duct through the epithelial sodium channel $\mathrm{ENaC}$ expressed in principal cells $[88,89]$. Increased electrogenic sodium reabsorption renders the transepithelial potential in the collecting duct more negative in the lumen. This potential difference facilitates proton secretion by neighboring intercalated cells [90]. Consequently, blockade of $\mathrm{ENaC}$ channels with inhibitors such as amiloride or triamterene reduces urinary acidification [90].

The aldosterone stimulated urinary acidification depending on $\mathrm{ENaC}$ activity forms the basis for a clinical test examining the ability of the connecting tubule and collecting duct to maximally acidify urine. This test is used in patients suspected to suffer from forms of incom-
Wagner 
plete or complete distal renal tubular acidosis as an alternative for the classic ammonium chloride loading test that is often not well tolerated. Patients are given a combination of mineralocorticoid analogues such as fludrocortisone to stimulate $\mathrm{ENaC}$ activity and a loop diuretic such as furosemide. Furosemide blocks the $\mathrm{Na} / \mathrm{K} / 2 \mathrm{Cl}^{-}$ cotransporter NKCC2 in the TAL and delivers more sodium to downstream segments thereby increasing sodium reabsorption by ENaC. In healthy subjects, urinary $\mathrm{pH}$ acidifies under such treatment below $\mathrm{pH} 5.4$ whereas in patients with impaired distal urinary acidification urinary $\mathrm{pH}$ remains more alkaline $[91,92]$.

This crosstalk between principal cells and intercalated cells may be even more complex as indicated above. In type I distal renal tubular acidosis, due to mutations of AE1 or the a4 and $\mathrm{B} 1 \mathrm{H}^{+}$-ATPase subunits, urinary salt and potassium wasting has been described which is not fully reversed by correction of acidosis [93, 94]. Experiments in mice lacking the $\mathrm{B} 1 \mathrm{H}^{+}$-ATPase subunit demonstrated an impaired ability to conserve $\mathrm{NaCl}$ and concentrate urine together with increased kaliuresis in view of elevated angiotensin II and aldosterone levels [28]. Defective intercalated cells may secrete ATP, increase prostaglandin production and thereby signal to neighboring principal cells where $\mathrm{ENaC}$ expression was reduced. Thus, potassium wasting in distal renal tubular acidosis may be at least in some patients caused by elevated aldosterone levels in combination with direct interactions between intercalated and principal cells [28, 94, 95].

\section{Role of Aldosterone in Acid-Base Balance in CKD}

In animal models and patients with reduced kidney function, renal acidosis develops and may contribute to the further decline in renal function [96-99]. In an earlier stage of reduced nephron numbers, acid-base balance is maintained and may depend on elevated angiotensin II levels [100]. In later stages of CKD (e.g. stage 4) enhanced aldosterone secretion may be promoted by stimulated endothelin production due to accumulation of acid in kidney and other tissues. Treatment of acidosis with alkali substitution reduces aldosterone in these patients [98]. Blockade of MR appears to slow down the rate of loss of GFR in a rat model of CKD [97]. How aldosterone alone or in conjunction with acidosis and other factors contributes to decline of renal function is an open question.

\section{Summary and Outlook}

Aldosterone is a very powerful regulator of acid-base balance and links this important function to the regulation of salt and potassium homeostasis. However, whereas acidosis and volume depletion are associated with elevated angiotensin II levels, hyperkalemia is not. Angiotensin II has a very strong direct stimulatory effect on renal excretion and appears to have also a permissive effect on genomic effects of aldosterone in intercalated cells by dephosphorylating the MR. Aldosterone stimulates both type A intercalated cells increasing urinary acid excretion as well as non-type A intercalated cells leading to enhanced activity of pendrin. Depending on the coupling of type A and non-type A intercalated cells this may result either in increased acid secretion, alkali secretion or acidbase neutral chloride reabsorption. However, the exact role of aldosterone and its interaction with other hormones and factors are only partly understood. Along the same line, the mechanisms that increase aldosterone secretion during acidosis are mostly unknown.

The molecular mechanisms of the non-genomic rapid effects of aldosterone as well as their physiological relevance are not fully explored. The effects occur in vitro and in vivo but whether it requires the MR or which other receptor(s) is/(are) involved has not answered. In view of the increasing number of non-genomic effects of steroid hormones, it is likely that aldosterone and other steroid hormones are able to activate alternative signaling routes $[101,102]$.

In patients with $\mathrm{CKD}$, the increased secretion of aldosterone induced by the renal retention of acid may turn from a protective mechanism into a factor contributing to the progression of disease. Whether blockade of aldosterone secretion or action, possibly in combination with neutralizing the acid overload, could be beneficial for patients with CKD remains to be shown.

\section{Acknowledgements}

Work in the laboratory of the author has been supported by grants from the Swiss National Science Foundation (SNSF) and the European Union FP7 COST action BM1301 (ADMIRE: Aldosterone and mineralocorticoid receptor: Pathophysiology, clinical implication and therapeutic innovations). 


\section{References}

1 Hamm LL, Alpern RJ, Preisig PA: Cellular mechanisms of renal tubular acidification; in Alpern RJ, Hebert SC (eds): Seldin and Giebisch's The Kidney Physiology and Pathophysiology. New York, Academic Press, 2008, pp 1539-1585.

2 Curthoys NP: Renal ammonium ion production and excretion; in Alpern RJ, Hebert SC (eds): Seldin and Giebisch's The Kidney Physiology and Pathophysiology. Philadelphia, Elsevier, 2008, pp 1601-1619.

-3 Christensen EI, Wagner CA, Kaissling B: Uriniferous tubule: structural and functional organization. Compr Physiol 2012;2:805-861.

$\checkmark 4$ Wagner CA, Devuyst O, Bourgeois S, Mohebbi N: Regulated acid-base transport in the collecting duct. Pflugers Arch 2009;458:137156.

5 Ackermann D, Gresko N, Carrel M, LoffingCueni D, Habermehl D, Gomez-Sanchez C, Rossier BC, Loffing J: In vivo nuclear translocation of mineralocorticoid and glucocorticoid receptors in rat kidney: differential effect of corticosteroids along the distal tubule. Am J Physiol Renal Physiol 2010;299:F1473F1485.

-6 Biner HL, Arpin-Bott MP, Loffing J, Wang X, Knepper M, Hebert SC, Kaissling B: Human cortical distal nephron: distribution of electrolyte and water transport pathways. J Am Soc Nephrol 2002;13:836-847.

$>7$ Loffing J, Loffing-Cueni D, Valderrabano V, Klausli L, Hebert SC, Rossier BC, Hoenderop JG, Bindels RJ, Kaissling B: Distribution of transcellular calcium and sodium transport pathways along mouse distal nephron. Am J Physiol Renal Physiol 2001;281:F1021F1027.

8 Lang F, Quehenberger P, Greger R, Silbernagl $\mathrm{S}$, Stockinger P: Evidence for a bicarbonate leak in the proximal tubule of the rat kidney. Pflugers Arch 1980;386:239-244.

-9 Orlowski J, Grinstein S: Diversity of the mammalian sodium/proton exchanger SLC9 gene family. Pflugers Arch 2004;447:549-565.

$>10$ Romero MF, Fulton CM, Boron WF: The SLC4 family of $\mathrm{HCO}_{3}{ }^{-}$transporters. Pflugers Arch 2004;447:495-509.

-11 Capasso G, Unwin R, Rizzo M, Pica A, Giebisch G: Bicarbonate transport along the loop of Henle: molecular mechanisms and regulation. J Nephrol 2002(suppl 5):S88-S96.

$>12$ Jakobsen JK, Odgaard E, Wang W, Elkjaer ML, Nielsen S, Aalkjaer C, Leipziger J: Functional up-regulation of basolateral $\mathrm{Na}^{+}$-dependent $\mathrm{HCO}_{3}^{-}$transporter NBCn1 in medullary thick ascending limb of $\mathrm{K}^{+}$-depleted rats. Pflugers Arch 2004;448:571-578.

$\checkmark 13$ Moret C, Dave MH, Schulz N, Jiang JX, Verrey $\mathrm{F}, \mathrm{W}$ agner CA: Regulation of renal amino acid transporters during metabolic acidosis. Am J Physiol Renal Physiol 2007;292:F555F566.
14 Broer S: The SLC38 family of sodium-amino acid co-transporters. Pflugers Arch 2014;466: 155-172.

15 Wagner CA, Devuyst O, Belge H, Bourgeois S, Houillier P: The rhesus protein RhCG: a new perspective in ammonium transport and distal urinary acidification. Kidney Int 2011; 79:154-161.

16 Stettner P, Bourgeois S, Marsching C, Traykova-Brauch M, Porubsky S, Nordstrom V, Hopf C, Koesters R, Sandhoff R, Wiegandt H, Wagner CA, Grone HJ, Jennemann R: Sulfatides are required for renal adaptation to chronic metabolic acidosis. Proc Natl Acad Sci USA 2013;110:9998-10003.

17 Wagner CA, Finberg KE, Breton S, Marshansky V, Brown D, Geibel JP: Renal vacuolar $\mathrm{H}^{+}$-ATPase. Physiol Rev 2004;84:1263-1314.

18 Weiner ID, Hamm LL: Molecular mechanisms of renal ammonia transport. Annu Rev Physiol 2007;69:317-340.

19 Biver S, Belge H, Bourgeois S, Van Vooren P, Nowik M, Scohy S, Houillier P, Szpirer J, Szpirer C, Wagner CA, Devuyst O, Marini AM: A role for rhesus factor Rhcg in renal ammonium excretion and male fertility. Nature 2008;456:339-343.

20 Bourgeois S, Bounoure L, Christensen EI, Ramakrishnan SK, Houillier P, Devuyst O, Wagner CA: Haploinsufficiency of the ammonia transporter Rhcg predisposes to chronic acidosis: Rhcg is critical for apical and basolateral ammonia transport in the mouse collecting duct. J Biol Chem 2013;288:5518-5529.

21 Bounoure L, Ruffoni D, Muller R, Kuhn GA, Bourgeois S, Devuyst O, Wagner CA: The role of the renal ammonia transporter Rhcg in metabolic responses to dietary protein. J Am Soc Nephrol 2014;25:2040-2052.

22 Hamm LL, Simon EE: Roles and mechanisms of urinary buffer excretion. Am J Physiol 1987;253:F595-F605

23 Nowik M, Picard N, Stange G, Capuano P, Tenenhouse HS, Biber J, Murer H, Wagner CA: Renal phosphaturia during metabolic acidosis revisited: molecular mechanisms for decreased renal phosphate reabsorption. Pflugers Arch 2008;457:539-549.

24 Aruga S, Wehrli S, Kaissling B, Moe OW, Preisig PA, Pajor AM, Alpern RJ: Chronic metabolic acidosis increases NaDC- 1 mRNA and protein abundance in rat kidney. Kidney Int 2000;58:206-215.

25 Wagner CA, Hernando N, Forster IC, Biber J: The SLC34 family of sodium-dependent phosphate transporters. Pflugers Arch 2014; 466:139-153.

26 Royaux IE, Wall SM, Karniski LP, Everett LA, Suzuki K, Knepper MA, Green ED: Pendrin, encoded by the Pendred syndrome gene, resides in the apical region of renal intercalated cells and mediates bicarbonate secretion. Proc Natl Acad Sci USA 2001;98:4221-4226.
27 Wagner CA, Mohebbi N, Capasso G, Geibel JP: The anion exchanger pendrin (SLC26A4) and renal acid-base homeostasis. Cell Physiol Biochem 2011;28:497-504.

28 Gueutin V, Vallet M, Jayat M, Peti-Peterdi J, Corniere N, Leviel F, Sohet F, Wagner CA, Eladari D, Chambrey R: Renal $\beta$-intercalated cells maintain body fluid and electrolyte balance. J Clin Invest 2013;123:4219-4231.

29 Jacques T, Picard N, Miller RL, Riemondy KA, Houillier P, Sohet F, Ramakrishnan SK, Busst CJ, Jayat M, Corniere N, Hassan H, Aronson PS, Hennings JC, Hubner CA, Nelson RD, Chambrey R, Eladari D: Overexpression of pendrin in intercalated cells produces chloride-sensitive hypertension. J Am Soc Nephrol 2013;24:1104-1113.

30 Wesson DE, Simoni J, Green DF: Reduced extracellular $\mathrm{pH}$ increases endothelin-1 secretion by human renal microvascular endothelial cells. J Clin Invest 1998;101:578-583.

31 Khanna A, Simoni J, Hacker C, Duran MJ, Wesson DE: Increased endothelin activity mediates augmented distal nephron acidification induced by dietary protein. J Am Soc Nephrol 2004;15:2266-2275.

32 Khanna A, Simoni J, Wesson DE: Endothelininduced increased aldosterone activity mediates augmented distal nephron acidification as a result of dietary protein. J Am Soc Nephrol 2005;16:1929-1935.

33 Eiam-Ong S, Hilden SA, King AJ, Johns CA, Madias NE: Endothelin-1 stimulates the $\mathrm{Na}^{+}$/ $\mathrm{H}^{+}$and $\mathrm{Na}^{+} / \mathrm{HCO}_{3}{ }^{-}$transporters in rabbit renal cortex. Kidney Int 1992;42:18-24.

-34 Laghmani K, Preisig PA, Moe OW, Yanagisawa M, Alpern RJ: Endothelin-1/endothelin$B$ receptor-mediated increases in NHE3 activity in chronic metabolic acidosis. J Clin Invest 2001;107:1563-1569.

35 Pallini A, Hulter HN, Muser J, Krapf R: Role of endothelin-1 in renal regulation of acidbase equilibrium in acidotic humans. Am J Physiol Renal Physiol 2012;303:F991-F999.

36 Kalhoff H, Rascher W, Diekmann L, Stock GJ, Manz F: Urinary excretion of aldosterone, arginine vasopressin and cortisol in premature infants with maximum renal acid stimulation. Acta Paediatr 1995;84:490-494.

37 Perez GO, Oster JR, Vaamonde CA, Katz FH: Effect of $\mathrm{NH}_{4} \mathrm{Cl}$ on plasma aldosterone, cortisol and renin activity in supine man. J Clin Endocrinol Metab 1977;45:762-767.

38 Yamauchi T, Harada T, Kurono M, Matsui N: Effect of exercise-induced acidosis on aldosterone secretion in men. Eur J Appl Physiol Occup Physiol 1998;77:409-412.

39 Gyorke ZS, Sulyok E, Guignard JP: Ammonium chloride metabolic acidosis and the activity of renin-angiotensin-aldosterone system in children. Eur J Pediatr 1991;150:547549. 
-40 Nowik M, Kampik NB, Mihailova M, Eladari D, Wagner CA: Induction of metabolic acidosis with ammonium chloride $\left(\mathrm{NH}_{4} \mathrm{Cl}\right)$ in mice and rats - species differences and technical considerations. Cell Physiol Biochem 2010 26:1059-1072.

-41 Schambelan M, Sebastian A, Katuna BA, Arteaga E: Adrenocortical hormone secretory response to chronic $\mathrm{NH}_{4} \mathrm{Cl}$-induced metabolic acidosis. Am J Physiol 1987;252:E454E460.

-42 Henger A, Tutt P, Riesen WF, Hulter HN, Krapf R: Acid-base and endocrine effects of aldosterone and angiotensin II inhibition in metabolic acidosis in human patients. J Lab Clin Med 2000;136:379-389.

-43 Augustinsson O, Johansson K: Ammonium chloride induced acidosis and aldosterone secretion in the goat. Acta Physiol Scand 1986; 128:535-540.

-44 Jones GV, Wall BM, Williams HH, Presley DN, Sapir DG, Cooke CR: Modulation of plasma aldosterone by physiological changes in hydrogen ion concentration. Am J Physiol 1992;262:R269-R275.

45 Guagliardo NA, Yao J, Bayliss DA, Barrett PQ: TASK channels are not required to mount an aldosterone secretory response to metabolic acidosis in mice. Mol Cell Endocrinol 2011;336:47-52.

-46 Raff H, Jankowski B: Effect of $\mathrm{CO}_{2} / \mathrm{pH}$ on the aldosterone response to hypoxia in bovine adrenal cells in vitro. Am J Physiol 1993; 265:R820-R825.

-47 Rothenberger F, Velic A, Stehberger PA, Kovacikova J, Wagner CA: Angiotensin II stimulates vacuolar $\mathrm{H}^{+}$-ATPase activity in renal acid-secretory intercalated cells from the outer medullary collecting duct. J Am Soc Nephrol 2007; 18:2085-2093.

-48 Geibel J, Giebisch G, Boron WF: Angiotensin II stimulates both $\mathrm{Na}^{+}-\mathrm{H}^{+}$exchange and $\mathrm{Na}^{+} /$ $\mathrm{HCO}_{3}{ }^{-}$cotransport in the rabbit proximal tubule. Proc Natl Acad Sci USA 1990;87:79177920.

49 Nagami GT: Enhanced ammonia secretion by proximal tubules from mice receiving $\mathrm{NH}_{4} \mathrm{Cl}$ : role of angiotensin II. Am J Physiol Renal Physiol 2002;282:F472-F477.

-50 Wagner CA, Giebisch G, Lang F, Geibel JP: Angiotensin II stimulates vesicular $\mathrm{H}^{+}$ATPase in rat proximal tubular cells. Proc Natl Acad Sci USA 1998;95:9665-9668.

- 51 Wagner CA, Mohebbi N, Uhlig U, Giebisch GH, Breton S, Brown D, Geibel JP: Angiotensin II stimulates H-ATPase activity in intercalated cells from isolated mouse connecting tubules and cortical collecting ducts. Cell Physiol Biochem 2011;28:513-520.

52 Levine DZ, Iacovitti M, Buckman S, Harrison $\mathrm{V}$ : In vivo modulation of rat distal tubule net $\mathrm{HCO}_{3}$ flux by VIP, isoproterenol, angiotensin II, and ADH. Am J Physiol 1994;266:F878F883.

Mineralocorticoids in Acid-Base Balance
3 Levine DZ, Iacovitti M, Buckman S, Burns KD: Role of angiotensin II in dietary modulation of rat late distal tubule bicarbonate flux in vivo. J Clin Invest 1996;97:120-125.

54 Liu FY, Cogan MG: Angiotensin II: a potent regulator of acidification in the rat early proximal convoluted tubule. J Clin Invest 1987;80: 272-275.

55 Nagami GT: Role of angiotensin II in the enhancement of ammonia production and secretion by the proximal tubule in metabolic acidosis. Am J Physiol Renal Physiol 2008; 294:F874-F880.

56 Wagner CA, Geibel JP: Acid-base transport in the collecting duct. J Nephrol 2002;15(suppl 5):S112-S127.

57 Schlatter E, Haxelmans S, Ankorina I, Kleta R: Regulation of $\mathrm{Na}^{+} / \mathrm{H}^{+}$exchange by diadenosine polyphosphates, angiotensin II, and vasopressin in rat cortical collecting duct. J Am Soc Nephrol 1995;6:1223-1229.

58 Karet FE: Mechanisms in hyperkalemic renal tubular acidosis. J Am Soc Nephrol 2009;20: 251-254.

59 Reyes AJ, Leary WP, Crippa G, Maranhao MF, Hernandez-Hernandez R: The aldosterone antagonist and facultative diuretic eplerenone: a critical review. Eur J Intern Med 2005;16:3-11.

60 Sebastian A, Sutton JM, Hulter HN, Schambelan M, Poler SM: Effect of mineralocorticoid replacement therapy on renal acid-base homeostasis in adrenalectomized patients. Kidney Int 1980;18:762-773.

61 Mitsuuchi Y, Kawamoto T, Naiki Y, Miyahara K, Toda K, Kuribayashi I, Orii T, Yasuda K, Miura K, Nakao K, et al: Congenitally defective aldosterone biosynthesis in humans: the involvement of point mutations of the P450C18 gene (CYP11B2) in CMO II deficient patients. Biochem Biophys Res Commun 1992;182:974-979.

62 Geller DS, Rodriguez-Soriano J, Vallo Boado A, Schifter S, Bayer M, Chang SS, Lifton RP: Mutations in the mineralocorticoid receptor gene cause autosomal dominant pseudohypoaldosteronism type I. Nat Genet 1998;19: 279-281.

63 Eiam-Ong S, Kurtzman NA, Sabatini S: Regulation of collecting tubule adenosine triphosphatases by aldosterone and potassium. J Clin Invest 1993;91:2385-2392.

64 Boyden LM, Choi M, Choate KA, NelsonWilliams CJ, Farhi A, Toka HR, Tikhonova IR, Bjornson R, Mane SM, Colussi G, Lebel M, Gordon RD, Semmekrot BA, Poujol A, Valimaki MJ, De Ferrari ME, Sanjad SA, Gutkin M, Karet FE, Tucci JR, Stockigt JR, KepplerNoreuil KM, Porter CC, Anand SK, Whiteford ML, Davis ID, Dewar SB, Bettinelli A, Fadrowski JJ, Belsha CW, Hunley TE, Nelson RD, Trachtman H, Cole TR, Pinsk M, Bockenhauer D, Shenoy M, Vaidyanathan P, Foreman JW, Rasoulpour M, Thameem F, AlShahrouri HZ, Radhakrishnan J, Gharavi AG, Goilav B, Lifton RP: Mutations in kelch-like 3 and cullin 3 cause hypertension and electrolyte abnormalities. Nature 2012;482:98-102.
65 Wilson FH, Disse-Nicodeme S, Choate KA, Ishikawa K, Nelson-Williams C, Desitter I, Gunel M, Milford DV, Lipkin GW, Achard JM, Feely MP, Dussol B, Berland Y, Unwin RJ, Mayan H, Simon DB, Farfel Z, Jeunemaitre X, Lifton RP: Human hypertension caused by mutations in WNK kinases. Science 2001;293: 1107-1112.

66 Lifton RP, Dluhy RG, Powers M, Rich GM, Cook S, Ulick S, Lalouel JM: A chimaeric $11 \beta$-hydroxylase/aldosterone synthase gene causes glucocorticoid-remediable aldosteronism and human hypertension. Nature 1992;355:262-265.

67 Lifton RP, Dluhy RG, Powers M, Rich GM, Gutkin M, Fallo F, Gill JR Jr, Feld L, Ganguly A, Laidlaw JC, Murnaghan DJ, Kaufman C, Stockigt JR, Ulick S, Lalouel JM: Hereditary hypertension caused by chimaeric gene duplications and ectopic expression of aldosterone synthase. Nat Genet 1992;2:66-74.

68 Beuschlein F, Boulkroun S, Osswald A, Wieland $T$, Nielsen $H N$, Lichtenauer UD, Penton D, Schack VR, Amar L, Fischer E, Walther A, Tauber P, Schwarzmayr T, Diener S, Graf E, Allolio B, Samson-Couterie B, Benecke A, Quinkler M, Fallo F, Plouin PF, Mantero F, Meitinger T, Mulatero P, Jeunemaitre X, Warth R, Vilsen B, Zennaro MC, Strom TM, Reincke M: Somatic mutations in ATP1A1 and ATP2B3 lead to aldosteroneproducing adenomas and secondary hypertension. Nat Genet 2013;45:440-444, 444e12.

69 Tauber P, Penton D, Stindl J, Humberg E, Tegtmeier I, Sterner C, Beuschlein F, Reincke M, Barhanin J, Bandulik S, Warth R: Pharmacology and pathophysiology of mutated KCNJ5 found in adrenal aldosterone producing adenomas. Endocrinology 2014; 155: 1353-1362.

70 Luke RG, Galla JH: It is chloride depletion alkalosis, not contraction alkalosis. J Am Soc Nephrol 2012;23:204-207.

71 Shibata S, Rinehart J, Zhang J, Moeckel G, Castaneda-Bueno M, Stiegler AL, Boggon TJ, Gamba G, Lifton RP: Mineralocorticoid receptor phosphorylation regulates ligand binding and renal response to volume depletion and hyperkalemia. Cell Metab 2013;18: 660-671.

72 Thompson A, Bailey MA, Michael AE, Unwin RJ: Effects of changes in dietary intake of sodium and potassium and of metabolic acidosis on $11 \beta$-hydroxysteroid dehydrogenase activities in rat kidney. Exp Nephrol 2000;8: 44-51.

73 Gros R, Ding Q, Sklar LA, Prossnitz EE, Arterburn JB, Chorazyczewski J, Feldman RD: GPR30 expression is required for the mineralocorticoid receptor-independent rapid vascular effects of aldosterone. Hypertension 2011;57:442-451.

74 DuBose TD Jr, Caflisch CR: Effect of selective aldosterone deficiency on acidification in nephron segments of the rat inner medulla. J Clin Invest 1988;82:1624-1632. 
75 Winter C, Schulz N, Giebisch G, Geibel JP, Wagner CA: Nongenomic stimulation of vacuolar $\mathrm{H}^{+}$-ATPases in intercalated renal tubule cells by aldosterone. Proc Natl Acad Sci USA 2004;101:2636-2641.

-76 Winter C, Kampik NB, Vedovelli L, Rothenberger F, Paunescu TG, Stehberger PA, Brown $\mathrm{D}$, John $\mathrm{H}$, Wagner CA: Aldosterone stimulates vacuolar $\mathrm{H}^{+}$-ATPase activity in renal acid-secretory intercalated cells mainly via a protein kinase C-dependent pathway. Am J Physiol Cell Physiol 2011;301:C1251-C1261.

-77 Stone DK, Seldin DW, Kokko JP, Jacobson HR: Mineralocorticoid modulation of rabbit medullary collecting duct acidification. A sodium-independent effect. J Clin Invest 1983; 72:77-83.

78 Hulter HN, Ilnicki LP, Harbottle JA, Sebastian A: Impaired renal $\mathrm{H}^{+}$secretion and $\mathrm{NH} 3$ production in mineralocorticoid-deficient glucocorticoid-replete dogs. Am J Physiol 1977;232:F136-F146.

-79 Hays SR: Mineralocorticoid modulation of apical and basolateral membrane $\mathrm{H}^{+} / \mathrm{OH}^{-} /$ $\mathrm{HCO}_{3}{ }^{-}$transport processes in the rabbit inner stripe of outer medullary collecting duct. J Clin Invest 1992;90:180-187.

80 Mohebbi N, Perna A, van der Wijst J, Becker HM, Capasso G, Wagner CA: Regulation of two renal chloride transporters, AE1 and pendrin, by electrolytes and aldosterone. PLoS One 2013;8:e55286.

81 Verlander JW, Hassell KA, Royaux IE, Glapion DM, Wang ME, Everett LA, Green ED, Wall SM: Deoxycorticosterone upregulates PDS (Slc26a4) in mouse kidney: role of pendrin in mineralocorticoid-induced hypertension. Hypertension 2003;42:356-362.

\$82 Wall SM, Kim YH, Stanley L, Glapion DM, Everett LA, Green ED, Verlander JW: $\mathrm{NaCl}$ restriction upregulates renal Slc26a4 through subcellular redistribution: role in $\mathrm{Cl}^{-}$conservation. Hypertension 2004;44:982-987.

\$83 Pelzl L, Pakladok T, Pathare G, Fakhri H, Michael D, Wagner CA, Paulmichl M, Lang F: DOCA-sensitive pendrin expression in kidney, heart, lung and thyroid tissues. Cell Physiol Biochem 2012;30:1491-1501.
Adler L, Efrati E, Zelikovic I: Molecular mechanisms of epithelial cell-specific expression and regulation of the human anion exchanger (pendrin) gene. Am J Physiol Cell Physiol 2008;294:C1261-C1276.

85 Pech V, Kim YH, Weinstein AM, Everett LA, Pham TD, Wall SM: Angiotensin II increases chloride absorption in the cortical collecting duct in mice through a pendrin-dependent mechanism. Am J Physiol Renal Physiol 2007; 292:F914-F920.

86 Grossmann C, Gekle M: Interaction between mineralocorticoid receptor and epidermal growth factor receptor signaling. Mol Cell Endocrinol 2012;350:235-241.

87 Paunescu TG, Ljubojevic M, Russo LM, Winter C, McLaughlin MM, Wagner CA, Breton S, Brown D: cAMP stimulates apical VATPase accumulation, microvillar elongation, and proton extrusion in kidney collecting duct A-intercalated cells. Am J Physiol Renal Physiol 2010;298:F643-F654.

88 Loffing J, Zecevic M, Feraille E, Kaissling B, Asher C, Rossier BC, Firestone GL, Pearce D, Verrey F: Aldosterone induces rapid apical translocation of $\mathrm{ENaC}$ in early portion of renal collecting system: possible role of SGK. Am J Physiol Renal Physiol 2001;280:F675F682.

89 Rossier BC, Pradervand S, Schild L, Hummler E: Epithelial sodium channel and the control of sodium balance: interaction between genetic and environmental factors. Annu Rev Physiol 2002;64:877-897.

90 Kovacikova J, Winter C, Loffing-Cueni D, Loffing J, Finberg KE, Lifton RP, Hummler E, Rossier B, Wagner CA: The connecting tubule is the main site of the furosemide-induced urinary acidification by the vacuolar $\mathrm{H}^{+}$ATPase. Kidney Int 2006;70:1706-1716.

91 Walsh SB, Shirley DG, Wrong OM, Unwin RJ: Urinary acidification assessed by simultaneous furosemide and fludrocortisone treatment: an alternative to ammonium chloride. Kidney Int 2007;71:1310-1316.

92 Batlle DC: Segmental characterization of defects in collecting tubule acidification. Kidney Int 1986;30:546-554.
93 Sebastian A, McSherry E, Morris RC Jr: Impaired renal conservation of sodium and chloride during sustained correction of systemic acidosis in patients with type 1 , classic renal tubular acidosis. J Clin Invest 1976;58: 454-469.

-94 Sebastian A, McSherry E, Morris RC Jr: Renal potassium wasting in renal tubular acidosis (RTA): its occurrence in types 1 and 2 RTA despite sustained correction of systemic acidosis. J Clin Invest 1971;50:667-678.

$\checkmark 95$ Muto S, Asano Y, Okazaki H, Kano S: Renal potassium wasting in distal renal tubular acidosis: role of aldosterone. Intern Med 1992;31:1047-1051.

-96 Wesson DE, Nathan T, Rose T, Simoni J, Tran RM: Dietary protein induces endothelin-mediated kidney injury through enhanced intrinsic acid production. Kidney Int 2007;71:210-217.

-97 Wesson DE, Simoni J: Acid retention during kidney failure induces endothelin and aldosterone production which lead to progressive GFR decline, a situation ameliorated by alkali diet. Kidney Int 2010;78:11281135.

98 Wesson DE, Simoni J, Broglio K, Sheather $S$ : Acid retention accompanies reduced GFR in humans and increases plasma levels of endothelin and aldosterone. Am J Physiol Renal Physiol 2011;300:F830-F837.

99 De Brito-Ashurst I, Varagunam M, Raftery MJ, Yaqoob MM: Bicarbonate supplementation slows progression of CKD and improves nutritional status. J Am Soc Nephrol 2009;20:2075-2084.

100 Wesson DE, Jo CH, Simoni J: Angiotensin II receptors mediate increased distal nephron acidification caused by acid retention. Kidney Int 2012;82:1184-1194.

101 Thomas W, Harvey BJ: Mechanisms underlying rapid aldosterone effects in the kidney. Annu Rev Physiol 2011;73:335-357.

102 Dooley R, Harvey BJ, Thomas W: Non-genomic actions of aldosterone: from receptors and signals to membrane targets. Mol Cell Endocrinol 2012;350:223-234. 